in two areas: withers and junction of thoracic and lumbar vertebrae. The increase of the mean backfat thickness (9 p. I00) and that of the carcass length (6 p. 100) only partially explain the backfat weight gain, about $30 \mathrm{p}$. Ioo, between 80 and $100 \mathrm{~kg}$. The relationship between backfat thickness at different levels and backfat weight were very different in castrated and non castrated male pigs. As for the latter correlations were highest in the middle of the loin. Methods of estimating fatness from backfat thickness used in the other sexual types cannot be transposed to non castrated males.

\title{
COMPARAISONS DES CARACTËES ANATOMIQUES DE LA RÉGION DORSO-LOMBAIRE DES PORCS MALES ENTIERS « LARGE-WHITE » DE 80 ET 100 KG
}

\author{
B.-L. DUMONT et B. DESMOULIN* \\ Laboratoire de Recherches sur la Viande, \\ * Station de Recherches sur l'Élevage des Porcs, \\ Centre national de Recherches zootechniques, I.N.R.A., \\ 78350 Jouy en Josas
}

\section{RÉSUMÉ}

Sur des carcasses de porcs mâles entiers Large White abattus à 80 et roo $\mathrm{kg}$ de poids vif on a étudié les principales caractéristiques de la section transversale au niveau de la treizième côte et leurs liaisons avec d'autres critères d'appréciation de la composition de la carcasse (poids de la bardière, rapport longe/bardière, densité du " rein ").

I. Entre 80 et Ioo $\mathrm{kg}$, les mesures d'épaisseur du lard dorsal effectuées sur les sites latéraux, à $4,5 \mathrm{~cm}\left(\mathrm{P}_{1}\right)$ et à $6,5 \mathrm{~cm}\left(\mathrm{P}_{2}\right)$ de l'axe de la colonne vertébrale augmentent, de façon significative, respectivement de 15 et i 6 p. Ioo. Dans l'axe médian du corps (fente de la carcasse), l'épaisseur de lard n'augmente que de 7 p. Ioo.

L'accroissement de la surface de graisse sous-cutanée mesurée sur la section est de 22 p. roo et celui de la noix de côtelette de I6 p. Ioo.

2. La liaison entre la surface de graisse sous-cutanée et le poids de la bardière était, aux deux stades considérés, de $+0,86$ et $+0,82$, alors que les corrélations entre la surface de la noix de côtelette et le poids de la longe n'était, à 80 et Ioo $\mathrm{kg}$, que de $+0,58$.

Le rapport viande/graisse de la section (calculée d'après SIEBURG, 1957), s'est révélé fortement lié au rapport longe/bardière $(v=+0,9 \mathrm{I}$ et 0,90$)$, de même que l'indice de densité du rein $(r=+0,85$ et 0,89$)$.

L'application directe de ces résultats au contrôle des performances individuelles en station (performance-test) concerne la précision des méthodes d'amélioration génétique. 


\section{SUMMARY}

\section{ANATOMICAL, CHARACTERISTICS OF THE TRANSVERSE SECTION, BEHIND THE I3 TH RIB, OF ENTIRE MALE CARCASSES FROM LARGE WHITE PIGS OF 80 AND IOO KG LIVE WEIGHT}

Main anatomical characteristics of the transverse section of the carcass, behind the $\mathbf{I} 3$ thrib, were observed in entire male Large White pigs of 80 and $100 \mathrm{~kg}$ live weight in relation with others criteria of carcass composition (weight of backfat "bardière ", weight of rib-cut "longe ", " longe " / "bardière " ratio, density of the cut " rein "-consisting of " bardière + longe ").

I. From 80 to $100 \mathrm{~kg}$, backfat thickness over the lateral side of the carcass, at $4.5 \mathrm{~cm}\left(\mathrm{P}_{\mathbf{1}}\right)$ and $6.5 \mathrm{~cm}\left(\mathrm{P}_{2}\right)$ from the midline, increased, respectively, by 15 and $16 \mathrm{p}$. Ioo; on the midline, the increase of fat thickness was only $7 \mathrm{p}$. Ioo. The area of fatty tissue corresponding to the layer of sub-cutaneous fat covering the rib increased by $22 \mathrm{p}$. Ioo, and that of $\mathrm{m}$. Longissimus dorsi of 16 p. 100 .

2. There were rather close relationships $(r=0.86$ and 0.82 at 80 and $100 \mathrm{~kg})$ between the area of fatty tissue and the weight of backfat (" bardière "), whereas the correlation between the weight of "longe" and the area of eye muscle was only +0.58 for the two weights groups.

Meat/Fat ratio calculated from areas of fat and eye muscle in the cross-section (after SIEBURG, 1957) was higly correlated with the "Ionge " / "bardière " ratio $(r=0.9 \mathrm{r}$ and +0.90$)$, as it was also the case for the density of the cut " rein $)(r=+0.85$ and 0.89 , respectively at 80 and $\mathrm{Ioo} \mathrm{kg}$ live weight).

These results could be used to increase the accuracy of individual boar evaluation during the performance test achicved for genetical pork quality improvement. 